\title{
Do You Know where Your Money Is? Product Disclosure Statements for Discretionary Investment Services
}

\author{
Emily Lou \\ University of Auckland, Grafton, New Zealand \\ Email: klou016@aucklanduni.ac.nz
}

Received October 23 ${ }^{\text {rd }}, 2012$; revised November 25 ${ }^{\text {th }}, 2012$; accepted December $1^{\text {st }}, 2012$

\begin{abstract}
New Zealand capital markets currently do not serve retail investors well, creating investor skepticism regarding participation. A recent Reader's Digest survey rated financial advisers among the least trustworthy of professions. This article maps the legal implications of the new measures introduced by the Financial Markets Conduct Bill 2011 to guard investor interests in relation to financial products and services. The paper provides a useful critique of the proposed reforms, in particular, whether the "Product Disclosure Statement” (PDS) and the new licensing of fund managers will give retail investors confidence in investing through financial intermediaries. The paper concluded with recommendation for New Zealand regulator to obtain inspiration from overseas model.
\end{abstract}

Keywords: Securities Law; Product Disclosure Statement; Financial Intermediaries

\section{Introduction}

A widespread perception exists that New Zealanders prefer to invest in direct holdings of residential and commercial property rather than in capital markets. These preferences are unsurprising since the New Zealand capital markets currently do not serve retail investors well, creating investor scepticism regarding participation (Ministry of Economics, 2009). While retail investors are encouraged to seek advice from licensed advisers and intermediaries, scepticism about trusting their money to fund managers is common. "The global financial crisis is leading to a reassessment of financial sector regulatory settings around the world, with a greater focus on transparency" (Ministry of Economics, 2009). To make an informed decision about the purchase of a financial product investors require adequate information about the company offering the product, the product offered, and associated liabilities and risks.

A recent Reader's Digest survey rated financial advisers among the least trustworthy of professions (Marriner \& White, 2010). With 48 financial investment companies in New Zealand having gone out of business in the past three years, causing millions of dollars in losses to thousands of New Zealanders, it would have been surprising had the survey result been any different. Whether investors receive sufficient disclosure from their "agents" regarding the financial products into which their money is being invested is debatable. To address this situation, the New Zealand government has proposed new measures to licence fund managers and supervisors. Additionally, a replacement for the prospectus and investment statement, called the "product disclosure statement", has been proposed to address disclosure concerns (Office of Minister of Commerce, 2011). This article maps the legal implications of the new measures introduced by the Financial Markets Conduct Bill 2011 to guard investor interests in relation to financial products and services.

This article examines whether the Product Disclosure Statement (PDS) and the new licensing of fund managers will give retail investors confidence in investing through financial intermediaries, and provides suggestions regarding PDS disclosure for Discretionary Investment Management Services. Section Two defines financial intermediaries and addresses the issues associated with the provision of information to retail investors. Section Three presents a brief overview of the existing disclosure provisions and measures that safeguard investor interests in relation to investments made through an intermediary. Section Four discusses whether the proposed PDS increases the benefits to prospective investors from investing through Collective Investment Schemes. This section is supplemented by Section Five which discusses in detail whether the content of the new regime will benefit indirect retail investors who invest via Discretionary Investment Management Services rather than Collective Investment Schemes. Section Six suggests adopting a different framework based on the European/Australian model, with both Europe and Australia having introduced documents analogous to the PDS. Implications of requiring PDS disclosure for Discretionary Investment Management Service are discussed throughout.

\section{Financial Intermediaries and Disclosure Philosophies}

A complex financial system comprises both financial markets and financial intermediaries. Most securities regimes in New Zealand require retail investors to be responsible for their investment decisions, based on their assessment of their needs and the suitability of particular investments for meeting those needs. A financial intermediary is the most appropriate first port of call for retail investors who have weak investment literacy. However, the market for financial intermediaries is mixed, with advisers and fund managers having variable expertise and independence, and hence a poor collective reputation. Retail investors thus have difficulty knowing to whom they can turn for trusted service. Securities law regulates entities that invest in financial assets on behalf of others, doing so primarily by 
requiring the disclosure of certain information to retail investors and establishing governance requirements for issuers of secureties. Major reforms of securities law are underway, but poor implementation will cause as many problems as it resolves.

Retail Investors often lack understanding of and confidence in purchasing financial products. Meanwhile, financial intermediaries often take responsibility for managing client investments or savings, providing many circumstances in which potential exists for a fiduciary relationship to arise (Ministry of Economics, 2010). Numerous retail investors may share a financial interest in a single financial product, creating free rider and other collective action problems in monitoring the fund manager and acting in the event of a breach of duty. Since individual investors only own a small fraction of the Collective Investment Scheme, they receive only a fraction of the benefits, while bearing most of the costs. Where costs are disproportionate to the expected benefits, investors have only a limited incentive to monitor and intervene. Passivity serves investor self-interest, even if monitoring promises collective gains.

Financial products are often complex and difficult for nonexperts to evaluate; poor transparency makes it difficult to verify seller claims, and comparatively easy to conceal costs and risks (Ministry of Economics, 2010). Financial products cannot be tested before purchase, generally have no warranty, often require long-term commitments, are critical for investor wellbeing, and failures may take years to eventuate. Consequently, regulatory regimes require disclosure to allow retail investors to make informed choices.

Governance requirements set the requisite competencies, experiences and on-going duties that fund managers and others involved in investing or protecting investors' money must meet. The current governance requirements for collective investment schemes ensure that fund managers have appropriate skills, place duties on fund managers and trustees, and provide incentives for them to act in the best interests of investors. However, Collective Investment Schemes have diverse governance models and accountabilities, and hence varying levels of investor protection. Investors therefore cannot be confident that their funds will be invested in accordance with their best interests (Ministry of Economics, 2009).

\section{Who Are “Retail Investors”?}

The term "retail investors" refers to investors with varying levels of knowledge, aptitude and expertise in relation to understanding financial information, and to investors unable to access the same information as financial professionals. Retail investors have been described as "people who are very unengaged by financial matters", and "whose education is not up to analysing financial documents" (Australian Securities \& Investments Commission, 2011).

The Financial Markets Conduct Bill 2011 defines a "retail investor" as a "person who is not a wholesale investor", where "wholesale investors" include investment businesses, persons participating in substantial investment activities, large entities and government agencies. Furthermore, a person is a "wholesale investor" in relation to an investment offer if a minimum of $\$ 500,000$ is payable on acceptance of the offer, if the person previously paid a minimum of $\$ 500,000$ for the issuer's financial products of the same class, or if they are an "eligible investor" who certifies themselves as knowledgeable. "Eligible investors" are "either able to recognise deficiencies in the terms of the offer and reject it on that basis or have a relationship with the issuer that means they are unlikely to agree to unfavorable offers without obtaining the required information and seeking appropriate advice” (Ministry of Economics, 2010). Eligible investors may certify themselves as knowledgeable to access "private offers" which issuers only make available to sophisticated investors.

Most retail investors are non-expert investors with limited investment literacy, skills and experiences. Improving financial literacy and giving the public understandable financial information are currently hot topics. Previous frameworks, such as the Commission for Financial Literacy and Retirement Income, were set up to help financially illiterate New Zealanders prepare financially for retirement through education, information and promotion. Evidence from behavioural economics and surveys of financial literacy suggest that the public have a limited ability to understand financial information; thereby most disclosure documents are clearly inaccessible to their intended audience (Ministry of Economics, 2010). The ultimate objecttive of any investment literacy initiative should be to ensure that investors are as informed as they can be about their decisions and are aware of when they need to seek advice. Retail investors that lack the resources, time and commitment to research often delegate day-to-day investment decisions regarding their portfolios to a financial intermediary. Clear and understandable information is especially important when institutions are investing on behalf of retail investors, as the rebuilding of trust in capital markets is essential for investors.

Additionally, decision making by retail investors suffers from the presence of "intuitive thought", otherwise known as the use of heuristics. Reliance on unconscious thought that reduces complex decisions to simple thoughts leads to systematic error or biases. Investor cognitive capabilities limit the effectiveness of a disclosure regime in aiding investment decisions; accordingly, many investors rely on expert financial intermediaries to make decisions on their behalf.

\section{Who Are Financial Intermediaries?}

The term financial intermediaries generally refer to parties that acquire and/or dispose financial products on behalf of retail investors. Such parties have the expertise, time and information to break down the knowledge gap between providers and consumers to help achieve efficient resource allocation by matching consumers with products that best meet their needs and appetite. Financial intermediaries also help process information for investors, making useful information available to the public and benefiting the market by supporting more informed commentary and analysis (Ministry of Economics, 2010).

Financial intermediaries are particularly beneficial for investors who lack the time or skill to manage their own investments. The advent of financial intermediaries has introduced many more New Zealanders to the advantages of having fund manager (Ministry of Economics, 2009) invest their money and make decisions that, if competent, will achieve superior returns. Collective Investment Schemes are an important option, not least because they offer diversification through a combination of shares, bonds and property in a way that exceeds the capabilities of most investors. Retail investors are also encouraged to seek advice from financial service intermediaries and thus realize benefits such as asset growth, improved financial literacy, and better understanding of the reasons for purchasing 
specific financial products and associated goals.

Most investment schemes demand high emotional intelligence. Investors must resist fear and greed, the two great drivpers of investment. The challenges facing investors are now greater than ever. While frightening or exciting investment information has always existed, the volume and frequency at which investors receive such information, especially online, has never been greater. Investors must not allow these scrambled messages to distract them from their objectives. Therefore, over the last 30 years investors have increasingly employed professsional fund managers to administer their savings (Kathleen \& Bancorp, 2012). The Financial Markets Conduct Bill 2011 promotes robust safeguards for investors who entrust others to invest money on their behalf.

\section{Collective Investment Schemes}

A Collective Investment Scheme (CIS) is defined as "an intermediary, in whom a subscriber pays money to another person to invest, but the subscriber does not have day-to-day control over investment decisions or the assets purchased using his or her contributions" (Ministry of Economics, 2010). Fund managers in CIS are responsible for making investment decisions in accordance with the stated goals of the fund, and a relationship is created whereby an investor delegates decisions about their investment portfolio to fund managers (Ministry of Economics, 2010).

"Modern Portfolio Theory has taught us that the game of stock picking is costly and futile for most investors, especially small investors" Generally, retail investors do not have the resources, knowledge or skills to undertake this role themselves, and cannot access investment products that are reserved for sophisticated investors and institutions or require a large investment. In a CIS, money from individual investors is pooled and invested by a fund manager. CIS enable individual retail investors to access a diversified portfolio of investments, suited to their investment risk profile (Ministry of Economics, 2010). Unit trusts, group investment funds and superannuation schemes are the main types of CIS.

CIS have a fund manager, who is principally responsible for the day-to-day management of the scheme and of individual portfolios, including the implementation of investment strategies, and the promotion of the scheme and individual portfolios (Ministry of Economics, 2010). Unsophisticated retail investors may lack the time, ability or inclination to conduct detailed research to make informed investment decisions or effectively monitor fund managers. Instead, they rely on fund managers to have the specialist skills needed to invest successfully and to act with integrity and competence. CIS also involve trustees, who act on behalf of investors to monitor their investments, and might be responsible for checking that fund managers comply with the management agreement and invest in accordance with fund objectives (Ministry of Economics, 2010). Currently, regulation of CIS is sometimes inconsistent. The Financial Markets Conduct Bill 2011 defines CIS as financial products.

\section{Financial Adviser Services}

The Financial Markets Conduct Bill 2011 regulates financial adviser services to varying degrees via the Financial Market Authority. The degree of regulation depends on the type of financial adviser and the nature of their service. Financial advisers are those who use appropriate asset allocation to help clients maintain a desirable balance of investment income, capital gains, and risk. The Financial Advisers Act 2008 defines an adviser as a person who provides a "financial adviser service” $^{\text {"1 }}$ (s10), which includes a person who makes recommendations in relation to acquiring or disposing of a financial product, and/or who provides an "investment planning service” (s11).

According to the Financial Markets Conduct Bill 2011, financial adviser services also include "discretionary management services" (s12), but otherwise are defined the same as in the Financial Advisers Act $2008^{2}$. Essentially, this service involves managing individual investments under an investment authority, allowing investors to hand over day-to-day management of their investment portfolio to an authorised financial adviser, who monitors their holdings and acquires or disposes financial products on their behalf. The service provided by financial advisers differs from a CIS in that each investor individually holds the underlying financial product, rather than holding an interest in a scheme that invests in those products. The Financial Markets Conduct Bill 2011 treats licensed intermediaries offering discretionary management as providing a service rather than a product.

The Financial Advisers Act 2008 established a licensing regime for financial advisers that include standards for disclosure, competency and conduct, as well as a dispute resolution scheme (Ministry of Economics, 2010). However, whether retail investtors should rely solely on financial advisers remain debatable, as many financial advisers work for or receive commissions from issuers. Financial advisers offer no objectivity when they manage products of the companies they work for, since commissions create a natural conflict of interest. Investors must ensure they know exactly what they are purchasing, and should ask if other investments can achieve the same objective at lower cost and risk. The core problem is a lack of disclosure requirements, which means that shareholding structures and other financial relationships remain hidden.

\section{Legal Background}

Retail investors currently receive an "investment statement", and are entitled to receive a "prospectus" upon request ${ }^{3}$. Currently, regardless of security type, one set of requirements exists for investment statements of newly offered securities ${ }^{4}$. Little reliable comparative information exists regarding fees and returns on these products, meaning the available information is of little use to most retail investors (Ministry of Economics, 2009).

\footnotetext{
${ }^{1}$ Financial Advisers Act 2008.

${ }^{2}$ See, for example, the direct reference to s 12 of the Financial Advisers Act 2008 made in cl 415 (2) of the Financial Markets Conduct Bill 2011 when defining the meaning of "discretionary investment management service". See also the definition of "wholesale investors" in the Financial Markets Conduct Bill 2011 (Consultation Draft), s 1 cls 3 and 32 - 37; compare this with the Financial Advisers Act 2008, ss 5B-5D.

${ }^{3}$ Securities Act 1978, s 33 (1). The Securities Act 1978, ss 33 and 37 require an investment statement and prospectus to accompany all issues of "securities" to "the public". See also Geof Mortlock "New Zealand's Financial Sector Regulation" (2003) 66 RBNZ Bulletin 5 at 37; See generally Robert Jones Investment ltd v Gardner (1991) 6 NZCLC 68,514 (HC); Kiwi Cooperative Daries Ltd v Securities Commission (1994) 7 NZCLC 260,519 (HC); Securities Commission v Kiwi Co-operative Dairies Ltd (1995) 7 NZCLC 260,828 (CA)

${ }^{4}$ Securities Regulations 2009, schedule 13. A particular form of investment statement is required for moratorium proposals under the Securities (Moratorium) Regulations 2009.
} 
Collective investment schemes, which are often the most appropriate product for relatively unsophisticated investors wishing to enter the market, are currently regulated according to their legal form and how they are described, rather than their economic substance (Ministry of Economics, 2010). This situation allows issuers to avoid regulation by special structuring of securities (Ministry of Economics, 2010). For example, if the issuer structures CIS as equity (e.g. redeemable preference shares), they are not supervised by a trustee or statutory supervisor, do not have to comply with a trust deed, and can avoid disclosure specific to collective investment schemes ${ }^{5}$. The trustee, who is primarily responsible for the management and administration of the scheme, may use the trust deed to delegate many of these functions to the manager to perform on their behalf, meaning they owe no express standard of care to the investor.

\section{Problems with Existing Regulations}

\section{Lack of Transparent Disclosure}

New Zealand's regulatory regime for CIS has been reviewed by the International Monetary Fund and Morningstar (Rekenthaler, Swartzentruber, \& Sin-Yi Tsai, 2009), a provider of independent investment research. Both organisations judged New Zealand to have poor regulation of financial intermediaryies, particularly CIS, and identified issues of concern for investtors. Most of the identified issues involved disclosure and transparency, particularly a lack of transparency regarding fees and information telling investors exactly what they were investing in (Ministry of Economics, 2010).

Retail investors currently receive an "investment statement" from financial advisors, and are entitled to receive a "prospectus" upon request ${ }^{6}$. An investment statement provides key information in a "question and answer" format, and is an "advertisement" for the purposes of the Securities Act $1978^{7}$. The role of an investment statement is to assist prudent but non-expert persons in their decision-making, and to draw their attention to important information ${ }^{8}$. Information provided in the investment statement includes risks and returns, investment type, people involved in the issue and where to obtain more information ${ }^{9}$. The prospectus provides more detailed information about the offer and the circumstances of the issuer, and is particular to the investment type (Office of the Minister of Commerce, 2011).

Given that many retail investors have limited investment lit-

\footnotetext{
${ }^{5}$ An example of this classification is found in the Securities Act (Carbon Logic Limited) Exemption Notice 2007. The notice states "the securities being offered are redeemable preference shares, but the investment will operate closer in substance to a managed fund than an ordinary offer of equity securities. In particular, transfers of shares following the initial offer will be offered at a price determined by reference to the net asset value of the fund, rather than at a fixed price".

${ }^{6}$ Securities Act 1978, s 33 (1). The Securities Act 1978, ss 33 and 37 require an investment statement and prospectus to accompany all issues of "securities" to "the public". See also Geof Mortlock "New Zealand's Financial Sector Regulation” (2003) 66 RBNZ Bulletin 5 at 37; See generally Robert Jones Investment ltd v Gardner (1991) 6 NZCLC 68,514 (HC); Kiwi Cooperative Daries Ltd v Securities Commission (1994) 7 NZCLC 260,519 (HC); Securities Commission v Kiwi.

Co-operative Dairies Ltd (1995) 7 NZCLC 260,828 (CA).

Securities Act 1978 ss 2A, 38, 38C and 38E; and Securities Regulation 2009 sch 13.

${ }^{8}$ Securities Act 1978 s 38D.

${ }^{9}$ Securities Regulation 2009, sch 13.
}

eracy, most disclosure documents are clearly inaccessible to their intended audience (Ministry of Economics, 2010). Evidence from behavioural economics and surveys of financial literacy suggest that the general public have limited ability to understand financial information (Ministry of Economics, 2011). Moreover, disclosure documents are typically poorly structured, and too long and confusing. Additionally, the information presented in disclosure documents is not easily comparable across products even in the same product class, limiting the ability of investors to compare risk and return trade-offs and thus make informed decisions, as well as effective market competition (Ministry of Economics, 2010). Transparency in portfolio holdings allows investors to understand what funds invest in and where potential risks lie. New Zealand and Australia are the only two countries out of 22 countries studied by Morningstar that do not require financial advisors to provide their clients with portfolio holding information (Morningstar Fund Research, 2011).

The Capital Development Task Force concluded that the current disclosure regime is "not sufficiently standardised, concise, simple or understandable, and is of little use to most retail investors" (Ministry of Economics, 2009). Even where key information is disclosed in a concise and simple manner, individual firms cast their data in the most favourable light, making it difficult to compare products (Ministry of Economics, 2009). This is particularly true of fees disclosure for CIS. Fees are a key element in investment decisions, but different providers often calculate and classify them differently. Overall, the current information disclosure regime is costly for issuers and yet largely ineffective for investors (Ministry of Economics, 2010).

\section{Lack of Regulatory Certainty}

Current regulation of CIS contains numerous gaps and is inconsistent across different legal structures (Ministry of Economics, 2010). The inconsistency of governance and legal obligations across the various legal forms that CIS can adopt has led to inconsistency in both investor rights and fund manager duties. Consequently, no minimum standards exist to protect investors.

Where regulation imposes governance standards, these need to be as consistent as possible between like products to avoid misleading and confusing retail investors. Particularly, the ability of issuers to name products differently from the underlying economic substance of the investment inhibits the ability of investors to make informed decisions (Ministry of Economics, 2010). Currently, KiwiSaver, unit trusts and superannuation schemes, which all involve contracting out investment decisions to a professional or third party, have different regulatory regimes, with different duties owed to investors. This situation creates confusion for investors and provides scope for regulatory arbitrage, whereby firms capitalise on regulatory loopholes to circumvent unfavourable regulation.

Currently companies can choose to issue specially structured shares with rights equivalent to debt security or interests in a CIS, but which the Securities Act treats as equity securities (Ministry of Economics, 2010). Securities law generally imposes fewer regulatory requirements on equity securities than other securities. For example, by structuring debt as equity, the issuer is not supervised by a trustee, and does not have to comply with a trust deed. Where instruments are not clearly categorized as equity or debt, categorisation is largely left to the issuer 
and their choice of description.

Multiple CIS structures with different oversight and obligetions for fund managers can also be difficult for investors to understand and differentiate. This complexity can reduce the effectiveness of monitoring of schemes and fund managers. A lack of proper monitoring and enforcement can lead to a lack of competition, as investors cannot easily determine which schemes are better managed and provide good value for money (Ministry of Economics, 2010).

\section{Inadequate Duties Owed by Fund Managers}

The current regulatory regime contains gaps that allow conduct damaging to investors. In a CIS, an agent essentially manages investor money and invests on their behalf. Where the scope of the direct relationship with individual investor is unclear, the risk that issuers of CIS will not act in the best interest of investors significantly increases (Ministry of Economics, 2011). Controversy around fund performance figures issued by Huljich Funds Management is a good example. For some of the current CIS structures used in New Zealand, (e.g.: KiwiSaver) only the trustee or statutory supervisor owes a direct duty of care to investors.Therefore, they are primarily responsible for the accuracy of disclosure documents and advertisements and owe a legal duty of care to investors.The fund manager of CIS has only a contractual relationship with the trustee and no direct duty to investors. Accordingly Fund Manager of Huljich allegedly made misleading claims about the performance of the Huijich KiwiSaver scheme (Mace, 2011). Peter Huijich has been fined \$112,500 in the Auckland District Court for misleading investor through disclosures about his KiwiSaver scheme (Fletcher, 2010).

The fund management agreement, a contract between the trustee or statutory supervisor and the manager, determines the obligations on the manager of a CIS. Investors are not party to the fund management agreement or any delegation documentation (such as the investment management contract). Problems can arise because the fund manager typically is also the fund founder. This situation places the fund manager in the driving seat when negotiating the terms of the contract with the trustee or statutory supervisor. Consequently, the standards in the contract will not necessarily be in the best interests of the investors and are often insufficient to mitigate the conflicts of interest inherent within investment schemes (Ministry of Economics, 2010). The fund manager of a unit trust ${ }^{10}$ owes some specific duties to investors, but these duties remain unclear to industry participants and investors, are difficult and expensive for individuals to enforce, and remain little tested in law (Ministry of Economics, 2010).

CIS contain significant assets owned by a dispersed group of investors but controlled by a fund manager with considerable ability to control information flows. Investors in a financial product often have very limited means of assessing the capacity of the issuer to deliver on their promises and claims, therefore it

\footnotetext{
${ }^{10}$ Unit Trust Act 1960 S2(1). See Unit trust means any scheme or arrangement, whether made before or after the commencement of this Act, that is established under New Zealand law and that is made for the purpose or has the effect of providing facilities for the participation, as beneficiaries under a trust, by subscribers or purchasers as members of the public and not as an association, in income and gains (whether in the nature of capital or income arising from the money, investments, and other property that are for the time being subject to the trust.
}

is important that fund managers of CIS observe a high standard when operating the scheme as well as providing sufficient disclosures.

\section{The Proposed Reforms}

\section{Addressing Lack of Disclosure}

The Financial Markets Conduct Bill 2011 proposes introducing new guidelines for securities issuers, directors and their advisers, to replace the current system of pre-vetting prospectuses and investment statements with a requirement for a single product disclosure statement (PDS) tailored to the needs of retail investors. The PDS should be standardised, concise, simple and understandable to facilitate the comparison of competing products (Office of the Minister of Commerce, 2011). The PDS would target less sophisticated investors and be presented in a way that induces such investors to read and understand it (Ministry of Economics, 2011). Once issuers became familiar with producing these type of short PDS, these documents would be less costly for issuers to prepare than the current investment statement (Ministry of Economics, 2010).

Australia and New Zealand are the only two nations among the 22 countries surveyed in the Morningstar Global Investor Experience 2012 study without mandatory disclosure of portfolio holdings (Kathleen \& Bancorp, 2012). Disclosure of portfolio holdings refers to public release of the specific stocks, bonds and other securities that constitute the portfolios of pooled investment vehicles. The MED proposes that fund managers provide regular access to a breakdown of their funds to better inform investors of how much of their money is invested in shares versus property, bonds and cash (Ministry of Economics, 2010).

Substantially similar products in the PDS will be disclosed in the same way to enable comparability between similar products on offers, while ensuring investors receive the most relevant information (Ministry of Economics, 2010). Standardization would be greatest for CIS. The new rules would require all collective investments to report performance and returns, fees and costs, and other key information in a uniform presentation standard that facilitates comparison of funds (Ministry of Economics, 2010). The industry has always objected to such disclosure, saying it would lead to individual managers copying competitors. This attitude reveals a mind-set that was criticised by the Capital Market Development Taskforce, which said that fund managers and their supervisors should be directly responsible for putting investor interests first (Ministry of Economics, 2009). Investors thus should be armed with as much information as possible, right down to the companies or securities their money is invested in.

\section{Addressing Regulatory Uncertainty}

The Financial Markets Conduct Bill 2011 proposes creating a single regime that would apply to all structures that are, in substance, collective investment schemes. The legal form of schemes would be flexible, but would have to comply with a common set of substantive requirements to ensure consistent minimum investor protections (Ministry of Economics, 2010). This approach is one of the "substance over form", if a scheme falls within the definition of CIS, then it will be captured by the regime and it will be required to meet the substantive regulatory requirements for CIS (Ministry of Economics, 2010). This 
would ensure consistent regulation of financial products, and would limit opportunities for issuers to avoid regulation through careful transaction structuring.

The Bill prescribes a standardized set of duties for all fund managers and trustees, regardless of investment vehicle type. All CIS will have a fund manager, which would be the issuer, and an independent supervisor (e.g. for a trust, the trustee; or for a company, an independent supervisor). While a mandated set of duties is desirable, the duties of fund managers and trustees would need to be sufficiently flexible to accommodate the various legal forms of CIS, or provision would need to be made for exemptions dependent on circumstances. Relatively high duties would provide appropriate accountability to investors, and are unlikely to impose significant cost since many of the duties already exist in legislation.

\section{Addressing the Inadequate Duties Owed by Fund Managers}

The Bill assigns scheme managers primary responsibility for scheme management and administration, including offering and issuing interests in the scheme and managing scheme assets (Ministry of Economics, 2011). The scheme manager will be legally responsible for investment decisions and owe direct duty to the member, even if they have delegated this function to an investment manager. Managers will be required to act in the best interests of members and to exercise the care, diligence, and skill that a prudent person acting as a professional manager would exercise in managing the affairs of others. Providers and fund managers putting investor interests first will increase competition among CIS.

CIS must be externally supervised, and supervisors owe particular duties to investors. The role of supervisors will be to ensure that issuers are accountable, protect investor assets from fraudulent practices, and provide investors with mechanisms to monitor issuers and participate in collective decision making (Ministry of Economics, 2010). Particularly, supervisors will be responsible for ensuring the custody of scheme assets and supervising specific requirements such as pricing and valuation. Both supervisors and fund managers will be registered as financial service providers under the FSPA, and belong to a consumer dispute resolution scheme that provides investors practical access to redress. Supervisors will be licensed in accordance with the regime set out in the Securities Trustees and Statutory Supervisors Bill (Ministry of Economics, 2010).

The Financial Market Conduct Bill 2011 requires that managers of CIS and financial intermediaries offering investment services be licensed unless exempted. Licensing should provide greater protection for investors by ensuring fund managers are "fit and proper persons", and providing for direct regulatory oversight (Ministry of Economics, 2010). Licensing is intended to ensure issuers protect investor interests, are subject to consistent minimum standards of entry, are competent to carry out their functions, are of good and sound character, and that the Authority is satisfied they will act honestly and with integrity in performing their functions.

In many ways, the Bill will merely result in New Zealand fund managers catching up to best practice in other parts of the world. Under the Bill, both investors and the industry will be better off, with investors enjoying improved protections and consequently more investors putting their money into CIS.

\section{Problems with the Proposed Reforms}

\section{Collective Investment Scheme vs Discretionary Investment Service}

A closer examination of the Financial Markets Conduct Bill reveals that a Collective Investment Scheme (CIS) is a licensed intermediary regulated as a "financial product"11; meanwhile, a financial adviser providing a Discretionary Investment Management Service (DIMS) is considered to be a licensed intermediary providing a financial "service" rather than a product ${ }^{12}$. Consequently, investments offered by financial advisers are excluded from the definition of "financial product" "13. Under the bill, PDS will only be provided to retail investors making direct investments through CIS, since offers for DIMS are deliberately exempt from disclosure using a PDS ${ }^{14}$.

Licensed providers of prescribed intermediary services must provide retail investors with a "Service Disclosure Statement" at the earliest opportunity and before giving any financial advice ${ }^{15}$. Disclosure statements provide information to help retail investors decide whether to purchase the market services offered by the licensee, or provide the licensee with fresh instructions related to service provision ${ }^{16}$. Restated, investors who invest through a licensed intermediary will not compulsorily receive a PDS, and therefore will not necessarily possess information on the financial product in which their money is invested. Authorised advisers providing DIMS thus would be responsible for judging the adequacy of the information and assurances provided by the issuer and hence making sound investment decisions.

Conceptually, exempting Licensed Service Intermediaries from providing investors a PDS may be appropriate, since such investors rely on the expertise and ability of the adviser to make investment decisions for them. Investment advisers provide investment advice or investment planning services to clients, and a service disclosure statement may be sufficient, as it informs investors of the limitations of the service provided. However, since the new Financial Advisers Act 2008 is still close to implementation, such an exemption could be seen as a legislative endorsement, as it relies on advisers to voluntarily provide product disclosures, especially given the recent finance company collapses. The public currently has little confidence in financial advisers, or in providing them additional exemptions, and it may not be in the interests of investors for government to boost their confidence via legislative endorsement (Institute of Finance Professionals New Zealand Inc, 2010). Trust needs to be earned instead of legislated.

On the one hand, investors in a pooled CIS can be considered more vulnerable in relation to DIMS, and thus to require more

\footnotetext{
${ }^{11}$ Financial Markets Conduct Bill 2011 (consultation draft), cl 9(2), sch1 cls $6-7$.

${ }^{12}$ Financial Markets Conduct Bill 2011 (MED 1235489 explanatory note) at [31-33].

${ }^{13}$ Financial Markets Conduct Bill 2011 (consultation draft), cl 9 (2)(c), schl 1 cls $6-7$.

${ }^{14}$ Financial Markets Bill 2011 (consultation draft), sch 1 cls 6 - 7.

${ }^{15}$ Ibid, cl 404.

${ }^{16}$ Financial Advisers Act 2008, s 23, the disclosure statement is required to provide information such as : financial adviser type; services provided; fees and remuneration; any material interests, relationships or associations; dispute resolution arrangements; relevant professional or business experience; criminal convictions; disciplinary proceedings; advise findings by the court or the FMA; and any bankruptcy ot other insolvency proceedings.
} 
protection via a PDS disclosure. Managers of CIS make all the decisions about which securities to invest in and when and investors lack direct control over their portfolio. Additionally, if the interests of individual investors conflict with those of the fund as a whole, the interests of the fund will always prevail. Any fiduciary duty is owed to investors as a group, namely to the scheme, and not to investors individually. Similarly, the liquidity policies of CIS are not always fair to investors, particularly where the scheme is underperforming. For example, a scheme having difficulty liquidating assets might allow investors to redeem their units on a first come first served basis. Until the scheme is "rebalanced" with more liquid assets, investors remaining in the scheme are then exposed to higher risk, and those exiting the scheme benefit at their expense.

On the other hand, DIMS generally involve the relevant investments being held in trust for individual investors. Authorised advisers manage each investor's funds in an individual account, and therefore DIMS resemble a service rather than a product. DIMS do not require the same level of supervision as pooled vehicles, as fewer issues arise with investor entry and exit. Individual investors have more direct ownership and ultimate control of the financial asset. Ultimately, no significant regulatory gap exists in relation to such schemes. To the extent to which they dispense advice or handle client money, various regulations already apply to financial intermediaries. The Financial Service Providers Act requires such investment services to be registered and, where available to retail clients, covered by a dispute resolution scheme. Likewise, the Financial Advisers Act 2008 established a licensing regime for financial advisers that include standards of disclosure, competency and conduct, as well as a dispute resolution scheme. This paper focuses on whether DIMS should be subject to mandatory PDS provision, and whether the services of financial intermediaries should be regulated in the same way as collective investment products in other respects, such as the duties of the fund manager. Scheme governance is not discussed in detail.

Nevertheless, the main consideration is management rather than direct versus indirect ownership of the underlying scheme. In substance, authorised advisers operating DIMS are providing an equivalent service to fund managers offering a CIS, which allows retail investors to delegate their day-to-day investment decisions and portfolio management to an investment service expert. The fundamental difference between DIMS and funds is that DIMS offer personal service, in which an authorised adviser monitors and manages a portfolio in accordance with parameters agreed with the relevant client (Fund Advisers, 2011), whereas CIS offers a group service in which assets are pooled for efficiency and convenience. Pooling should not be the basis for judging the level of investor protection. The Bill is intended to protect retail investors with weak investment literacy, obviously including those whose lack of knowledge leads them to allow experts to acquire and dispose financial products on their behalf. Pooling is not a useful concept in determining whether a PDS should be required. The author believes that over time technology will likely progress to enable product providers to offer an individual account style product which is substantially a CIS but avoids critical safeguards such as a PDS, because it technically does not pool investor assets.

\section{Practical Consequences of Differing Disclosure Set Ups}

Under the exemption from PDS disclosure for licensed service intermediary, the adviser providing a DIMS is responsible for judging whether the information and assurances provided by the issuer are adequate. This is analogous to the role played by a CIS (Ministry of Economics, 2010). When a retail investor invests in a fund, the fund manager makes the investment on their behalf. However these investments are subject to PDS disclosure obligations under the Financial Markets Conduct Bill. There are consequences in having different disclosure set ups between a CIS and a DIMS. Since the dominant purpose of regulating disclosure about financial products is to seek to balance information asymmetries, as the issuer-or in this case the DIMS advisers-are expected to possess more relevant and specific information about who is offering the financial product, the product itself and the terms and conditions on which it is managed than the investor is expected to possess (Ministry of Economics, 2010). This information asymmetry disadvantages the investor, resulting in an inefficient DIMS market.

Information asymmetry refers to the situation where one party, usually the seller, has information that is not available or understandable to the other party, usually the buyer (Kukoc, 1998). Product providers have an incentive to misinform or not inform investors about product shortcomings (Ministry of Economics, 2010). DIMS advisers may be reluctant to reveal unfavourable information about product risks and returns, as that would reduce investors' demand for their service and the amount of fees they could charge. Hirshleifer et al. (2002) employs "behavioral models", which assume that there are two types of consumers: fully rational consumers, who could correctly infer from a DIMS' disclosure the relevant quality; and boundedly rational consumers, who naively neglect to draw inferences from the fact that the DIMS does not disclose product information. The presence of boundedly rational consumers introduces at least some incentive for a DIMS adviser not to disclose information about product quality, even if it is costless, although they will have an incentive to reveal favourable information. In situation of selective disclosure, the market mechanism will still work but with a longer time for adjustment and with unnecessary loss resulting from the consumption of time and cost, and from experience-based adjustment.

The lack of product disclosure for a DIMS can also create adverse selection situations, where investors cannot distinguish between different risk classes of DIMS. This type of situation might have a significant effect on competitive DIMS markets. Within each risk category, some people will have a higher than average risk of loss and some a lower than average risk. Those with higher than average risk will tend to find a DIMS attracttive and buy it, and those with lower than average risk will not. The more people from the first group and the fewer from the latter who buy DIMS, the higher the average risk. As a result, the price of DIMS goes beyond an actuarially fair level. To quote Rothschild and Stiglitz: "the high-risk individuals exerted a dissipative externality on the low-risk individuals" (Rothschild \& Stiglitz, 1976). Therefore, an improved flow of information from policy makers to financial intermediaries is an important precondition for actuarially fair pricing of financial products and an efficient financial service market.

Disclosure of financial products' information is a critical precondition for a better and more effective financial market. It stimulates better performance and enhances the transparency and accountability of market participants. PDS disclosure can help regulators to reduce the risk of losses arising from the financial failure of the DIMS. Differing disclosure regimes between CIS and DIMS result in information not being pre- 
sented in a standard way to investors, and in investors not being able to compare DIMS services directly with pooled vehicles such as a CIS through point of sale PDS and ongoing disclosures. The overall lack of meaningful information, combined with limited investment options, results in a low level of investor trust and confidence in the DIMS sector. It is not difficult to see why many investors would prefer to invest in a CIS, as financial product information is often much easier for retail investors to understand and investors receive a greater level of protection in the form of PDS disclosure. Until retail investors feel they can trust financial advisers and understand what they are paying for, it is unlikely the use of DIMS will increase. A DIMS is a viable alternative to a CIS as it allows many of the same benefits as a CIS, such as economies of scale and access to a wider range of investments. There should be no unnecessary regulatory impediments to competition in the CIS sector. The ability of alternative products to compete in the CIS arena on a level playing field would be a useful strengthening of market discipline. For example, such competition would force more discipline in revealing true costs and portfolio transaction data. That would improve individual investors' ability to verify the performance of their long-term investment products (Ministry of Economics, 2009).

\section{Importance of Product Disclosure Information to Retail Investors}

Given the above findings, a key consideration is whether PDS should extend to schemes that do not involve pooling of investor funds. For example, DIMS involve an authorised adviser investing money from individual investors in assets held on trust and providing a return from those assets less fees. New Zealanders widely perceive the primary job of a DIMS adviser as being to pick a fund or fund manager that will deliver high returns. licensed services intermediaries are well regulated and policed via regulating organisations, such as professional bodies, legal regulations, the Financial Advisers Act, the courts ${ }^{17}$ and, most importantly, self regulation through reputational risk (Bank of New Zealand, 2010). Also offer documents and service information, such as information on fees, can be adequately disclosed through the Service Disclosure Statement. Unfortunately, investor "return" is largely determined by the predominant asset class. Studies over several decades show that assets held and holding structure determine investment portfolio performance. Allocation between asset types, and size of regular investor contributions to their portfolio, are the primary determinants of wealth accumulation. Recent studies found evidence that following the Global Financial Crisis, transparency has become more important for investors holding New Zealand funds (Kathleen \& Bancorp, 2012). PDS disclosure provides more detailed information allowing investors to better monitor DIMS investments. First, PDS can help identify overlaps in holdings and improve investor asset allocation and portfolio diversification. Second, increased transparency enables investors to better monitor fund compliance with stated objectives, thus enhancing investor confidence in the investment. Third, PDS disclosure improves investor ability to track portfolio manipulation, such as portfolio pumping ${ }^{18}$.

\footnotetext{
$\overline{{ }^{17} \text { In New Zealand auditors can be liable for failing to detect serious irregu- }}$ larities and frauds in a disclosure document if the circumstance give rise to a duty of care (Boyd Knight $v$ Purdue [1999] 2 NZLR 278 (CA)). The test, as set out in the UK decision of Caparo $v$ Dickman [1990] 2 AC605, is relatively narrow.
}

Exempting DIMS advisers from providing registered PDS could create significant problems. Investors who need experts to invest on their behalf are generally unsophisticated; if they lack the knowledge or resources to evaluate an issuer they are unlikely to be competent to evaluate an intermediary such as a DIMS adviser (Bank of New Zealand, 2010). Recent studies have found evidence that New Zealand authorised advisers providing DIMS are deviating from their stated investment objectives, with equity-oriented funds providing returns that differ significantly from underlying equity returns (Fowler, Grieves, \& Singleton, 2010). This further suggests that poor information about portfolio asset allocation limits opportunities for investors to diversify. Studies thus have found support for PDS disclosure requirements whereby DIMS advisers would disclose holdings and better serve investors. Investors who would previously have placed their money in the hands of authorised advisers and left them to it are now asking questions about risks and returns, and the products in which their money is invested. Clients want more options and easier access to those making decisions regarding their accounts. Many retail investors want more information from financial advisers, for example their reasons for selecting certain investments, or forecasts of capital gains for the coming year, either for educational purposes or piece of mind. Notably, some authorised advisors offering DIMS voluntarily disclose portfolio information via a PDS to encourage investors to invest. This suggests that effective product disclosure is required to assist investors, either on their own or with the assistance of advisers, to compare investments and allocate money to the best investment opportunities (Ministry of Economics, 2010).

The Financial Advisers Act 2008 provides New Zealanders engaging the services of a financial adviser with confidence that their adviser will have a minimum level of competency. However, the Act does not necessarily indicate the quality of provided advice. Irrespective of the Authorised Financial Adviser Regime, many investors are reluctant to trust advisors. The Financial Markets Conduct Bill and the Financial Advisers Act regime have been developed for separate policy reasons and so in principle should be complementary. The availability of a PDS should lead to more transparent performance reporting, and help retail investors understand and monitor the investment activities of the DIMS adviser. The fundamental principle of Securities Law is that the issuer has responsibility and liability for making necessary disclosures to retail investors (Bank of New Zealand, 2010). The reliance of investors on DIMS advisors creates responsibility for those advisors to provide a PDS.

\section{Standardised Disclosure to Improve Competition}

The main argument for regulating DIMS is that they can have fee structures, investment mandates, returns, and asset holdings similar to CIS. DIMS can be extremely attractive to retail investors by offering a specifically tailored investment objective and strategic product portfolio allocation implemented by an authorised adviser. For many investors, annual meetings with their authorised financial advisers are their only interaction with financial products. Provision of PDS thus is necessary to improve competition in the Licensed Service Industry and support investor competence, providing crucial dis-

\footnotetext{
${ }^{18}$ Portfolio pumping is the act of bidding up the value of a fund holdings before the end of a reporting period to boost fund performance results.
} 
closure of how funds invested will be managed, including investment style and type of financial products. Disclosure of PDS is important because it raises social welfare by improving investor choice, and improving DIMS product quality.

The Financial Markets Conduct Bill proposes that straightforward collective investment scheme PDSs be required to contain a summary of all of the key information a client needs before making a purchase decision. The PDS should follow a prescribed format, with a specified number of headings, topics, and in exceptional circumstances even prescribed text (Ministry of Economics, 2010). PDS content is prescribed in regulations, and is intended to be tailored for different products and designed to enhance the comparability of similar offerings ${ }^{19}$. This follows the approach taken to development of PDS in Australia, which is progressively working through the products to produce tailored documents, starting with CIS (Ministry of Economics, 2011). Since CIS can easily standardise information. Similarly, PDS for DIMS, which provide substantially the same service as CIS, should also have use an accessible format that retail investors can understand and use to make comparisons among alternatives. Comparable disclosure of functionally like investments is important. If disclosure regimes set different standards, and require the disclosure of different information and its presentation in irreconcilable formats, comparison of potential product returns will be impeded.

From the perspective of investors, numerous disclosure regimes have increased the difficulty of investment decisionmaking. Retail investors benefit from standardized presentation of their portfolio data. When portfolio information is not easily comparable across products even in the same product class the ability of investors to compare available risk and return tradeoffs and make informed decisions is impeded, as is competition in the DIMS market. However, the author notes the uncertainty regarding the implementation of standardizing portfolio reporting through PDS, as though these schemes were CIS. First, absolute uniformity of content is unnecessary, given that the nature of DIMS means disclosure is far more transactional for them than for CIS (Bank of New Zealand, 2010). The author thus agrees that where appropriate, PDS requirements for DIMS should be principle based ${ }^{20}$ and not overly prescripttive regarding presentation format.

\section{Alternative Approaches}

Other jurisdictions have chosen different frameworks for simplifying product disclosure requirements for financial intermediaries. Regulation aligned with international best practice can increase New Zealand's attractiveness to both domestic and international investors. New Zealand also has potential export opportunities as a domicile for international funds. However, realizing such opportunities requires a world class regulatory regime. Particularly, the New Zealand regime would need to match or better the European Union's Undertaking for Collective Investment in Transferable Securities regime (UCITS), which is generally considered the benchmark for international best practice (Ministry of Economics, 2010). Notably, Australian provisions regarding PDS have inspired the Financial Markets Conduct Bill, an obvious choice given the close Trans-

\footnotetext{
${ }^{19}$ Financial Markets Conduct Bill 2011 (342-1) (explanatory note) at [3].

${ }^{20}$ The principle based approach provides a flexible regulatory framework capable of adapting to structural and institutional changes in the financial system.
}

Tasman economic relationship and aspirations for a single market $^{21}$.

\section{The Product Disclosure Statement in Australia}

Most offers of securities to retail investors in Australia require a disclosure document, intended to help retail investors assess the risks and returns associated with an offer and make informed investment decisions. Retail clients receive numerous disclosure documents in the process of acquiring financial products through financial service providers; together these documents provide an integrated disclosure scheme (Central Bank of Ireland, 2007).

The Statement of Advice (SOA) ${ }^{22}$ should be prepared by a financial adviser providing personal advice, and should contain a statement setting out the advice and an explanation of the basis upon which it was given, as well as a disclaimer regarding advice based on incomplete client information. The SOA must indicate who provided the advice and detail any related remuneration or other benefit received by the adviser or their associates which could influence the content of their advice.

The Financial Service Guide (FSG) ${ }^{23}$ must be provided by a financial adviser before any financial service is provided, and gives the client information regarding the adviser's services and organisation. A licence holder or representative providing a financial service to a retail client must provide an FSG, prepared by the licence holder.

A Product Disclosure Statement (PDS) ${ }^{24}$ must contain sufficient information to enable a retail client to make an informed decision about whether to purchase a financial product. Generally an adviser, as the regulated person, will provide a PDS in situations where a retail client is advised about a product. The product provider must give a PDS to a retail client when making or receiving an offer by a client to take up the product ${ }^{25}$. An Australian PDS is used in Australia for investment products offered by licensed financial services.

The Australian product disclosure statement (“Australian PDS”) accompanies offers for financial products other than debentures and shares ${ }^{26}$. This includes bank deposits, life and general insurance, superannuation, derivatives, unit trusts and other managed investment schemes offered by regulated financial service providers. The content of the Australian PDS is

\footnotetext{
${ }^{21}$ Single Trans-Tasman Market, which allows an issuer to offer securities or interest in CIS in Australia and New Zealand using one disclosure document prepared under regulation in its home country.

${ }^{22}$ Corporation Act 2001 (Cth) s946C (1). See also, Corporation Amendment Regulation 2005 (No.5) at 27-28.

${ }^{23}$ Corporation Act 2001 (Cth), s941A, 941B, 941(D).

${ }^{24}$ Ibid s 761A, See also Div 2 Pt7.9.

${ }^{25}$ Australian Securities and Investment Commission Disclosure: Product Disclosure Statements (and Other Disclosure Obligations) (Regulatory Guide 168, 6 September 2010) at 6.

${ }^{26}$ Corporation Act 2011 (Cth), ss 762A - 765A, 1012A - 1012C. See also Marcus Best "Securities Law in Australia” in Jeanluc Soulier and Marcus Best (Eds.) International Securities Law Handbook (2nd ed., Kluwer Law International, The Netherlands, 2005) at 27. Investments in Australia are classified as either securities or financial products other than securities. Offers for investments in securities, that is shares and debentures, are accompanied by a full prospectus, as required by Chapter 6D of the Corporation Act 2011 (Cth). Offers for financial products other than securities are regulated by Part 7.9 of the Corporation Act 2011 (Cth), which requires issuers to prepare a product disclosure statement (Australian PDS). The Australian PDS is more concise than a prospectus, being intended to provide investors with sufficient information to help them make informed acquisitions of financial products. See James McConvill. An Introduction to CLERP 9 (LexisNexis, Australia, 2004) at 140.
} 
regulated and includes information on product benefits and risks associated with the product, rights and obligations attached to the product, a dispute resolution system covering complaints by holders of the product, and a description of methods for system assessment. The PDS must also contain any other information that might be expected to materially influence a reasonable person making an investment decision ${ }^{27}$.

\section{The Key Investor Information Document in the European Union}

The EU commission has replaced the simplified prospectus of investment funds with a new form of disclosure called the Key Investor Information Document (KIID) (Burn, 2010). In 2006, the European Commission extensively reviewed the framework for retail investment funds, including introducing the "UCITS" Directives for collective investment securities (Directive 2009/65/EC, 2009) and criticised the simplified prospectus introduced by the Management Company Directive (2001/107/EC) in 2002, for its length, complexity and lack of transparency. Most importantly, the Commission noted that the simplified prospectus did not aid in comparing different funds across member states. The Commission concluded that investtors required a new document communicating key information to support informed choices, enable consumers to compare funds, and facilitate cross-border marketing and enhanced competition between fund promoters (Burn, 2010). The new EU regulations prescribe that the KIID should be a single document of limited length written in concise and non-technical language, and should be provided to prospective investors in collective investment schemes pursuant to the Undertaking for Collective Investment in Transferrable Securities "UCITS" Directives (European Commission Internal Market and Services, 2007).

UCITS are open-ended investment vehicles in which investment units are repurchased or redeemed out of fund assets (art. 1). UCITS are designed to allow CIS to operate freely throughout the EU based on the authorization of a single member state. Unlike with a public limited company that coordinates the distribution and management of unit trusts amongst countries within the European Union, investors in UCITS funds generally purchase shares in the fund directly from the fund itself rather than from existing shareholders (art. 5).

UCITS are defined as retail products and so must suitably disclose their investment strategies to enable retail investors to make informed decisions (Central Bank of Ireland, 2007). Unsophisticated investors may not fully understand the different risk and return characteristics of these products, although some complex strategies may be less risky than some traditional long only structures (Central Bank of Ireland, 2007). Investors may purchase directly from the provider, an agent tied to the provider, or an intermediary. In the UK, considerable diversity exists within each of these channels. For example, a tied representative will sometimes offer an advisory service to the customer, but on other occasions will not. The dominant distribution channel for UCITS (either direct or packaged within unit-linked life insurance contracts) remains Independent Financial Advisers. FERI-Fund Market Information research found that in the UK, almost three-quarters of retail investment funds are distributed via advisers, with $16 \%$ distributed via

\footnotetext{
${ }^{27}$ Corporation Act 2011 (Cth), s 1013E.
}

insurance wrappers and 9\% via bank networks (Association of British insurer, 2006).

\section{Implications for Prescribing New Zealand's Product Disclosure Statement}

In Australia provision of the Product Disclosure Statement is limited to financial products offered by licensed financial services $^{28}$. The Corporation Act (Cth) imposes strict conduct and disclosure obligations on licensed financial product dealers, in addition to financial requirements and adequate risk management systems ${ }^{29}$, providing protection for investors. For example, when providing "personal advice" to retail investors making an investment $^{30}$, a product dealer must make reasonable inquires regarding the relevant personal circumstances of the client and give reasonable consideration to the subject matter of the advice $^{31}$. Moreover, when providing investors "general advice", a product dealer must warn them that the advice was prepared without considering their objectives or financial situations ${ }^{32}$.

The Australian Corporations Act defines a "financial product" as "a facility through which, or through the acquisition of which, a person makes a financial investment, manages financial risk or makes non cash payment”. The Act also specifies situations in which giving financial product advice that consists of, or includes, a recommendation to acquire a financial product gives rise to an obligation to provide a product disclosure statement (PDS) for that product. Similarly, where persons, such as the issuer of a financial product or a licensed financial service producer, offer to acquire a financial product on behalf of a retail investor, they must provide a PDS for that product.

Use of the KIID is currently limited to investments in UCITS funds (Burn, 2010), which are specially constituted for collective investment portfolios and heavily regulated for investor protection (Moloney, 2010) ${ }^{33}$. An independent authorised firm known as a "depository" holds the scheme assets and is also responsible for overseeing fund activities (Moloney, 2010). The directors of the depository must be of sufficiently good repute, and must have sufficient experience in relation to the UCITS they are managing (art 5(4)) (Directive 2009/65/EC, 2009). Disclosure is therefore more focused on the ability of the fund to provide investment returns, as the depository and Member State authorities monitor fund assets and management competence (Moloney, 2010).

The author argues that investors should benefit from several layers of protection to ensure their funds are managed according to the best internationally accepted fiduciary practices. Disclosure statements provided by licensed intermediaries should take stock from the Australian PDS and KIID and inform investors of where their money is going. The New Zealand PDS should also provide more information regarding the investment. Arguably, New Zealand regulators should draw on overseas models and either require disclosure of financial product information in the required service disclosure statement (Chen \& Watson, 2011), or extend PDS requirements to advisers providing DIMS.

\footnotetext{
${ }^{28}$ Corporation Act 2011 (Cth) ss 1012A - 1012C.

${ }^{29}$ ss $824 \mathrm{~B}, 912,945 \mathrm{~A}, 945 \mathrm{~B}, 946 \mathrm{~A}$ and $949 \mathrm{~A}$.

${ }^{30}$ ss $766 \mathrm{~B}$.

${ }^{31} \mathrm{~S} 945 \mathrm{~A}$.

${ }^{32}$ s $945 B$

${ }^{33}$ Malcony outlines three dimensions of the UCITS regime that protect investors: structure and investment policy; authorisation and supervision of the scheme manager and depository; and public marketing restrictions.
} 


\section{Recommendations}

\section{Disclosure Provisions for Discretionary Investment Management Service}

Regulators seeking drafting inspiration from the Australian PDS and the KIID must remember that these documents are only required for investments provided through licensed intermediaries, including both CIS and licensed service providers, while the Financial Markets Conduct Bill 2011 does not require preparation of a PDS for investments through licensed intermediaries $^{34}$. The only document that must accompany investments through licensed intermediaries is a "disclosure statement relating to the service" 35 . The risk here is that investors, the target audience of the PDS, are not required to be given a PDS, and may lack the knowledge to request one.

Licensed intermediaries providing a DIMS service are not subject to the same PDS requirement as CIS and may undermine the protections provided for by the financial market conduct bill. There is risk that financial advisers providing DIMS take money from individual investors and invest it on their behalf, possessing more information than the potential investors with whom they are dealing, will misstate future prospects through excessive optimism or deceit. The author proposes that the Ministry of Economic Development should wait and see how well the new Financial Advisers Act 2008 works in practice before granting exemption powers to advisers providing DIMS under the Bill. The author suggests that DIMS be subject to requirements equivalent to those CIS, specifically, the provision of a PDS to ensure equivalent regulation of similar services to improve competition, because the investment offer will not be scrutinised by an authorised adviser with a statutory duty to act in the best interest of the investor.

\section{Presentation of Fees and Performance Disclosure}

Investment management in New Zealand is expensive. Since many fund managers in New Zealand are also issuers, they have little incentive to minimize fees or highlight them to investors. Scale should allow cost reductions and advice fees based on the time and complexity of individual client situations, like in other professions based on individual contact between advisors and clients. Investors in CIS can rarely distinguish which expenses pay for which fund services. Investors require the information required to understand the costs of their funds, and to establish whether those costs are reasonable. While most countries require disclosure of fund expenses in ratio format in the prospectus (Morningstar Fund Research, 2011), so an investor can estimate the impact of expenses on fund performance, New Zealand only requires the presentation of actual expenses through fund financial statements. Consequently, no uniform standard exists in New Zealand for fee presentation (Morningstar Fund Research, 2011), making it very difficult for retail investors to assess the total cost of investing in a scheme since they must calculate the ratio themselves.

The Financial Markets Conduct Bill appears to be a big step forward in that it prescribes a standardised PDS for CIS to replace the investment statement and online entries on a public register to replace the prospectus. The Bill requires that the PDS be split into two parts and its contents heavily prescribed (Office of the Minister of Commerce, 2011). The first part of

\footnotetext{
${ }^{34}$ Financial Market Conduct Bill (Consultation Draft) sch 1 cls 6 - 7.

${ }^{35}$ Ibid, cl 404.
}

the PDS will summarise "key product information" and be restricted to two page (Office of the Minister of Commerce, 2011). The second part of the PDS, the main body, will contain more information considered "crucial to an investor's decision" (Office of the Minister of Commerce, 2011). The Financial Market Authority further issued a guidance note regarding effective disclosure which stated that PDS does not require a "key Information" section (Financial Market Authority, 2012) ${ }^{36}$. Instead, the FMA "Effective Disclosure” document only provides suggestions that fund managers should consider in setting factors such as fees charged to the fund, fees and expenses related to the fund, and their nature and effects on the investment statement. This contrasts sharply with best practice in the USA, where details of fees and performance must be set out in the first few pages of the key disclosure document for a managed fund. The author suggests that PDS disclosure for CIS be required to include a short (approximately two page) presentation of key information such as the benefits and risks associated with the investment and considered crucial by investors, and the use of simple language and communication tools such as graphs and numerical examples is preferred (Chen \& Watson, 2011). Information requiring disclosure is prescribed by law, and there is no need to decide what information is key, nor any discretion to include, or exclude, particular information.

\section{Emphasising the Importance of Seeking Financial Advice}

Currently the investment statement in New Zealand encourages prospective investors to "read all documents carefully" and "seek advice" before committing themselves ${ }^{37}$. The effectiveness of this statement has been questioned by a recent survey revealing the low numbers of New Zealanders who seek financial advice (RaboDirect, 2011). New Zealand has 1.7 million people participating in KiwiSaver and thus needing quality advice. That is a huge market given that New Zealand currently has just 2000 authorised financial advisers. Financial advice is cyclically depressed but structurally a long term growth business. The ANZ retirement commission's 2009 financial knowledge survey (Retirement Commission, 2009) found that 51\% of respondents used banks as their main source of advice, while $35 \%$ relied on friends and relatives. Instead of simply recommending that investors seek financial advice, the PDS should state that investors can confidently rely on that advice.

The Financial Advisers Act 2008 requires advisers who provide comprehensive advice to meet professional and ethical standards ${ }^{38}$. If the standards are breached investors can file complaints with an independent disputes resolution scheme and the FMA. If the situation cannot be resolved through the independent dispute resolution scheme, the FMA can act on behalf of investors, for example by seeking compensation for fraud or negligence $^{39}$. The author thus believes that this information should be provided in the two-page summary of the PDS to emphasise the benefits of using a financial adviser.

\footnotetext{
${ }^{36}$ See the key information section at the start of disclosure document for details of material risk to investors.

${ }^{37}$ Securities Regulation 2009, sch 13(1).

${ }^{38}$ Financial Advisers Act 2008, s 37. See also Code Committee Code of Professional Conduct for Authorized Financial Advisers (for the purpose of the Financial Advisers Act 2008).

${ }^{39}$ Financial Markets Authority Act 2011,s 34(1), as a result of an investigation under the Financial Advisers Act 2008, ss 96 and 97.
} 


\section{Conclusion}

Research house Morning Star rated New Zealand worst among 16 countries for best practice in fund management. Poor behaviour and incompetence from some financial intermediaries leads to low trust in financial advisers, and investor concerns that the regulatory regime may not protect them (Ministry of Economics, 2009). The fundamental objective of prescribing the PDS is to provide essential information for investment decisions (Office of the Minister of Commerce, 2011). This paper examined whether the proposed PDS disclosure should extend to licensed intermediaries providing discretionary investment services. The investigation focused on the disclosure needs of retail investors and was supplemented by an examination of how service intermediaries in Australia and the European Union adopted documents analogous to the PDS. This investigation yielded the following findings.

First, authorised advisers operating DIMS are in substance providing an equivalent service to fund managers offering CIS. Both services allow retail investors to delegate their day to day investment decisions and portfolio management to investment service experts. The author argues that pooling should not be the basis for assessing the degree of investor protection.

Second, the service disclosure statement that is currently required to be prepared by licensed intermediary services may be sufficient for advisers providing "investment planning services" and "financial adviser services" by recommending financial products to investors. The author believes that DIMS advisers, who acquire and dispose financial products on behalf of the investors warrant higher disclosure responsibilities, specifically disclosures regarding offered financial products.

Third, Investors would benefit from standardized presentation of their portfolio data. If disclosure regimes set different standards, and require the disclosure of different information, differing disclosure of fees, charges and commissions often make it impossible to compare future returns. Finally, the author found that it would be appropriate for New Zealand regulators to obtain inspiration from overseas models.

The problem suffered by the financial industry has presented regulators in New Zealand with an opportunity to implement major regulatory changes. The author believes that the government needs to ensure that efficiency, equity and confidence are present in licensed service intermediary markets so that retail investors have the best chance of achieving their objectives without fear of inappropriate behaviour by advisers to whom they have delegated authority. This applies particularly in relation to DIMS. Good regulation with appropriate disclosure of PDS can provide retail investors with confidence in investing through DIMS. In the current economy individuals require access to information on the financial products in which their money is invested.

\section{REFERENCES}

Association of British Insurer (2006). ABI response to CESR call for evidence key investor disclosure for UCITS (pp. 1-4). London: Association of British Insurer.

Australian Securities \& Investments Commission (2011). Regulatory guide 228 prospectuses: Effective disclosure for retail investors (pp. 1-60). Victoria.

Bank of New Zealand (2010). Submission to the ministry of economic development on the review of securities laws.

Brunton, C. (2009). Financial knowledge survey (pp. 1-178).
Burn, L. (2010). Kiss, but tell all: Short-form disclosure for retail investors. Capital Markets Law Journal, 5, 141-168.

Central Bank of Ireland (2007). Guidance note 3/07 Undertakings for Collective Investment in Transferable Securities (UCITS) structured products and complex trading strategies-prospectus disclosure requirements.

Chen, J., \& Watson, S. (2011). Investor psychology matters: Is a prescribed product disclosure statement a supplement for healthy investment decisions? New Zealand Business Law Quarterly, 17, 412435.

Directive 2009/65/EC (2009). Regulations and Administrative provisions relating to Undertaking Collective Investment in Transferable Securities (UCITS).

European Commission Internal Market and Services (2007). Simplified prospectus: Investor disclosure regime exposure draft: Initial orientations for discussion on possible adjustments to the UCITS directive (pp. 1-28). European Commission Internal Market and Services, Belgium.

Financial Market Authority (2012). Guidance note: Effective disclosure (pp. 1-53). Vaduz: Financial Market Authority.

Fletcher, H. (2010). Huljih fined for misleading KiwiSavers. New Zealand Herald. URL (last checked 15 October 2012). http://www.nzherald.co.nz

Fowler, R., Grieves, R., \& Singleton, J. (2010). New Zealand unit trust disclosure: Asset allocation, style analysis, and return attribution. Pacific Accounting Review, 22, 4-21. doi:10.1108/01140581011034191

Fund Advisers (2011). How discretionary management works. URL (last checked 20 May 2012).

http://www.fundadvisers.eu/DMS/discretionarymanagementservices

Institute of Finance Professionals New Zealand Inc. (2010). Submission to review of securities law-Discussion document part B answers to questions. Wellington: Institute of Finance Professionals New Zealand Inc.

Kathleen, B., \& Bancorp, T. (2012). The potential effects of mandatory portfolio holdings disclosure in Australia and New Zealand (pp. 1-57). Auckland: Massey University.

Khorana, A., Servaes, H., \& Wedge, L. (2007). Portfolio manager ownership and fund performance. Journal of Financial Economics, 85, 179-204. doi:10.1016/j.jfineco.2006.08.001

Kukoc, K. (1998) Information disclosure in a competitive insurance market-The government role. EconPapers, 87, 224-246.

Mace, W. (2011). Ex-fund manager up for sentencing. URL (last checked 20 May 2012). http://www.staff.co.nz

Marriner, K. \& White, R. (2010). Finance advisers and act MPs inspire mistrust. URL (last checked 29 June 2010).

http://www.nzherald.co.nz/business/news/article.cfm?c_id=3\&object id $=10655152$

Ministry of Economics (2009). Capital markets matter (pp. 1-124). Capital Market Development Taskforce.

Ministry of Economics (2010). Review of securities law discussion paper (pp. 1-200). Ministry of Economics.

Ministry of Economics (2011). Regulatory Impact Statement (pp. 1-28). Ministry of Economics.

Moloney, N. (2010) How to protect investors, lessons from the EC and the UK. Cambridge: Cambridge University Press. doi:10.1017/CBO9780511674808

Morningstar Fund Research (2011).Global fund investor experience 2011. URL (last checked 23 May 2012).

http://www.morningstar.co.nz/kiwisaver/article/morningstar-global-f und-experience/3527

Office of the Minister of Commerce (2011). Effective Disclosure paper to the chair of the cabinet economic growth and infrastructure committee: Securities law reform (pp. 1-91). Muang: Office of the Minister of Commerce.

Rekenthaler, J., Swartzentruber, M., \& Sin-Yi Tsai, C., (2009).Global fund investor experience, morningstar fund research. URL (last checked 1 April 2012). http://www.hk.morningstar.com

RaboDirect (2011). Public confidence in finance sector drops while people say investments worth more. URL (last checked 20 May 
2012). http://www.rabodirect.co.nz

Retirement Commission (2009). Finanancial knowledge surveySummary report (pp 1-11). Retirement Commission.

Rothschild, M., \& Stiglitz, J. (1976). Equilibrium in competitive insurance markets: An essay on the economic imperfect information. The Quarterly Journal of Economics, 90, 629-649.

$\underline{\text { doi: } 10.2307 / 1885326}$
Smith, D. K. (2004). Is "due diligence” dead? Financial service and product disclosure under the corporations act. Company and Securities Law Journal, 22, 128-150.

Technical Committee of the International Organisation of Securities Commissions (2009). Commissions principles on point of sale disclosure (Consultation report). URL (last checked 24 April 2012). http://www.iosco.eu 